\title{
THE RELATIONSHIPS BETWEEN MOBBING, ORGANIZATIONAL CITIZENSHIP BEHAVIOR AND TURNOVER INTENTION: A SURVEY STUDY IN ERZURUM/TURKEY
}

\author{
Orhan CCINAR \\ Atatürk University, Turkey
}

\begin{abstract}
The purpose of this study is to find out the relationships between mobbing, organizational citizenship behavior (OCB) and turnover intention in organizations. The data for this study was gathered from 171 public and private sector workers in the province of Erzurum/Turkey. As a result of the study, we found out that there was an inverse relationship between mobbing and OCB, whereas a strong and positive relationship between mobbing and turnover intention. Rather, there was no relationship between OCB and turnover intention. The level of mobbing was found as very low, the level of OCB was found as high and the level of turnover intention was found as very low. We observed that there were statistically significant differences between the levels of mobbing, OCB and turnover intention according to the demographic characteristics of workers.
\end{abstract}

Keywords: Mobbing, Organizational citizenship behavior, Turnover intention, Erzurum

\section{INTRODUCTION}

The human resources play a critical role in the activity of an organization in today competitive market. The development and survival of an organization are basically determined by human and intellectual capital. It can be said that a convenient view to human resource management and creating an organizational climate appreciated by workers and contributes to satisfying their needs, are necessary conditions to be successful. An organization, thus, can achieve its strategic goals.

In this study we investigated the relationships between mobbing, organizational citizenship behavior (OCB) and turnover intention of workers at workplace which are very important subjects to create positive conditions which are mentioned above.

Mobbing is commonly used to describe all situations where an employee, a supervisor, or a manager, is systematically, repeatedly mistreated and victimized by fellow workers, subordinates or superiors. As a result of such behaviors high turnover, low morale, increased absenteeism, decreased productivity and loss of key individuals were occurred. The term OCB as described extra discretionary work behavior has serious positive impact on work quality, actual performance, service quality and service delivery, good reputation etc., thus, corporate image. On top of them, lack of OCB affects the organizational performance as well as image in today's highly competitive business. Labor turnover is an important and widespread feature of the labor market. This affects both workers and organizations. Employees look for safer, secure and better work conditions. If they have negative concerns about this, they may intent to leave the organization. On the other hand companies suffer the loss of job-specific skills, disruption in production and undergo the costs of hiring and training new workers (Garino and Martin, 2007).

The study begins by a literature review of those concepts and then will go on to the development of hypotheses. Research methodology, research model and analyses results will take place at next sections. Then, the results of the analyses will be discussed and recommendations will be provided. 


\section{LITERATURE REVIEW}

\section{Mobbing}

The word "mobbing” was firstly used by Konrad Lorenz (1991) to describe animal group behavior. The attacks from a smaller animals group threatening a single larger animal were identified as "mobbing" by Lorenz. Later, Heinemann (1972) used this word for describing destructive behavior of small groups of children directed against a single child. When Leymann and Gustavsson (1984) found a similar kind of behavior at work places they borrowed this word and used. But the phenomenon (mobbing), first introduced by the American psychiatrist Carroll Brodksy (1976) in the book 'The harassed worker'. There are other expressions suggested for the same event at work. Those are: Psychological terror or mobbing (Leymann, 1990b), workplace bullying (Adams, 1992), work harassment (Einarsen and Raknes, 1997) and emotional abuse (Keashly, 1998). Leymann (1996) explains that bullying is used for physical aggression and threat acts at school but physical violence is very seldom found in mobbing behavior at work. As mobbing is characterized by much more sophisticated behaviors such as socially isolating the victim, Leymann (1996) suggests keeping the word "bullying" for activities between children and teenagers at school; hence he prefers to use psychological terror or mobbing.

All concepts refer to a situation where a worker over a long period of time is exposed to repeated and unwanted behavior merely directed against them or towards a group of employees by superiors or peers, creating an unpleasant psychosocial working environment as well as abasement, resentment and boredom in the target(s). The goal is to exclude, isolate, and eliminate the target(s) (Westhues, 2003). The International Labor Organization (ILO) recognizes emotional abuse as psychological violence, identifying bullying and mobbing as the two main forms of this violence (Denenberg and Braverman, 2001) . Leymann (1996) define mobbing as below:

"Psychological terror or mobbing in working life involves hostile and ethical communication, which is directed in a systematic way by one or a few individuals mainly towards one individual who, due to mobbing, is pushed into helpless and defenseless position, being held there by means of continuing mobbing activities. These actions occur on a very frequent basis (at least once a week) and over a long period of time (at least 6 months duration). Because of high frequency and duration of hostile behavior, this maltreatment results in considerable psychological, psychosomatic, and social misery."

When considering the phases of mobbing, five phases are typically suggested. The first is the initial conflict or critical incident stage. The second phase is where psychological abuse is increasingly directed at the target. The third phase occur when management intervenes, often siding with the perpetrators, and increasing the levels of harm. The fourth phase is recognizable when the target is accused of being 'difficult' or 'mentally ill' and the final phase is marked by the expulsion of the target from their employment (Shallcross et al, 2008).

Leymann (1996) says that mobbing causes negative effects on society, organizations and victims. For example, Leymann (1990) claimed that $15 \%$ of suicides in Sweden happened due to mobbing. He lists the causes of mobbing can be listed as follows: Poorly organized conditions, poor conflict management and personality of victim (Leymann, 1996). Sloan et al (2010) tabulated mobbing behaviors, changes experienced by target and organizational costs due to mobbing (Table1). 


\section{Table1. Mobbing Behaviors, Changes Experienced by Target and Organizational} Costs

\begin{tabular}{|l|l|l|}
\hline Mobbing Behavior & Changes Experienced by Targets & Organizational Costs \\
\hline Interrupts the target in meetings & Poor concentration & Loss of best employees \\
Sighs, rolls eyes, glares at target & Insomnia & Demoralization of staff \\
Discounts/discredits target's ideas and & Substance abuse & Resignations \\
accomplishments & Headaches & Unable to hire diverse staff \\
Ignores target (silent treatment) & Gastrointestinal disorders & Disruption of operations and staff relations \\
Intimidates through gestures & Depression & Company reputation suffers \\
Questions target's competence & Anxiety & Anxiety \\
Insults the target & Exhaustion & Decrease in productivity and creativity \\
Yells and screams & Suspicion & Increased absenteeism \\
Makes unreasonable demands & Fear & Loss of trust \\
Steals credit for work done by target & Forgetfulness & System stays in place when players change \\
Cuts target out of information loop & Fatigue & \\
Blames target for fabricated errors & Failure to pay bills & \\
Nice to target in public; makes rude & Crying & \\
comments to or about target in private & Irritability & \\
Constant criticism of target & Change in appearance & \\
Poisons workplace with angry outbursts & & \\
\hline
\end{tabular}

Leymann (1993) explains main reasons for engaging mobbing as follows:

1. To force someone to adapt to a group norm: "If they don't adapt, they have to go" would be the reasoning of someone driven by these motives. An overriding belief is that the group can only be cohesive and strong if uniformity exists.

2. To revel in animosity. People engage in mobbing to eliminate those they do not like. Relative position in organizational hierarchy does not really matter. Superiors, co-workers, or subordinates alike, when driven by personal dislikes, can initiate the process.

3. To gain pleasure. Sadistically motivated mobbers derive pleasure from the torment they inflict.

4. To reinforce prejudices. People use mobbing behaviors because they dislike or hate people who happen to belong to a certain social, racial, or ethnic group.

About mobbing process, Leymann (1996) propounds some measures directed toward preventing its development, stopping it, or rehabilitating a subjected individual: Precautions, early management interventions, vocational rehabilitation and law.

\section{Organizational citizenship behavior (ocb)}

Barnard (1938) stated that the willingness of individuals to contribute cooperative efforts to the organization was necessary to effective attainment of organizational goals. Katz and Kahn (1978) pointed out that organizational citizenship is important in organizations because it can be highly valuable to organizations and can contribute to performance and competitive advantage.

The concept of organizational citizenship behavior was first introduced by Organ (1988). Organ defined OCB as "individual behavior that is discretionary, not directly or explicitly recognized by the formal reward system, and that in the aggregate promotes the effective functioning of the organization". This means citizenship behavior includes voluntary employee activities that may or may not be rewarded but that contribute to the organization by improving the overall quality of the setting in which work takes place.

According to Organ's definition, OCB reflects a "good soldier syndrome" which is so necessary for the plenty and good functioning of an organization. It means doing a better job, making an effort above and beyond formal requirements, and filling the gap between procedures and regulations on the one hand, and dynamic reality on the other. OCB is usually understood as exerting exceptionally good behaviors for the sake of the organization and informally supporting its members. 


\section{Journal of Global Strategic Management | V. 9 | N. 1 | 2015-June | isma.info | 87-98 | DOI: 10.20460/JGSM.2015915631}

Coleman and Borman (2000) state that there are many different types of behaviors that might seem to fit the definition of citizenship behavior, but those could separated in two main categories that differ according to who benefits from the activity; coworkers or the organization. The first category of citizenship behavior is the one with which someone is likely to be familiar: interpersonal citizenship behavior. Such behaviors benefit coworkers and colleagues and involve assisting, supporting, and developing other organizational members in a way that goes beyond normal job expectations. The second category of citizenship behavior is organizational citizenship behavior. These behaviors benefit the larger organization by supporting and defending the company, working to improve its operations, and being especially loyal to it (Van Dyne and Le Pine, 1998).

OCB is very important to organizations because they need employees who will do more than their usual job duties and provide performance that is beyond expectations. OCB describe actions in which employees are willing to go above and beyond their prescribed role requirements. As Organ (1988) suggested, high levels of OCB should lead to a more efficient organization and help bring new resources into the organization. It is believed that as more employees engage in OCB, the organization becomes more successful in building corporate image and improving performance. Employees high on OCB rating will not show any counterproductive work behavior that can have negative effect on production, service delivery and promotion of corporate image (Kolade et al, 2014).

By reviewing the relevant literature of organizational citizenship behavior, it can be seen that there is a lack of consensus about the dimensions of OCB. Also the different labels used for the dimensions of OCB, the most relevant dimensions introduced by Organ (1988) are altruism, conscientiousness, courtesy, civic virtue and sportsmanship. Zhang (2011) explains these dimensions as follows. Altruism: Being helpful; Conscientiousness: Doing more than just the minimum; attention to detail (prevent/ minimize error); Courtesy: Being polite and courteous; prevent conflict; Civic virtue: Showing interest and involvement (e.g. keeping up to date) with the organization; defend organizational policies and practices and Sportsmanship: Tolerating less than ideal conditions; accepting of changes and performs requests without complaints.

\section{Turnover intention}

Human resources department is facing the challenge of retaining the employees in the organization to achieve organizational goals. On the other hand employees look for safer and secure work conditions. If they have negative concerns about this subject they may intent to leave the organization. Turnover intention can be defined as how long an employee wants to stay in an organization (Ahmad, et al, 2012). Intention to turnover shows an individual's perceived probability of staying or leaving in an organization (Cotton and Tuttle, 1986). Tett and Meyer (1993) describe turnover intentions as a conscious and deliberate willfulness to leave the organization. Employees are the most valuable resource of an organization. It is very important for management to understand employee's needs in order to implement the business plan effectively. Workforce turnover is considered a sticky phenomenon that causes problems for business. Losing the qualified workforce leads to reduction on quality, productivity, innovation and competitiveness. Furthermore, turnover causes significant cost in the recruiting and training the new employees (Abbasi et al., 2008).

Today it is considered to be an important task to manage employee turnover for any organization. It is natural that people want diversities in their everyday life; seeks for new and challenging jobs and good working environment in job place. Every organization wished to have high productivity, fewer turnovers and to be profitable. Managing turnover successfully is a must to achieve the organizational goals (Shamsuzzoha and Shumon, 2007).

Sometimes employee turnover benefits organizations positively. This might happen when a poor performer is replaced by a more skilled employee and when a retired employee replaced by a younger one (Shamsuzzoha and Shumon, 2007). Some mentioned about the benefits of turnover in settings requiring exploration or innovation. Dalton and Todor (1979) noted that the worker mobility meant by turnover may serve as a source of new knowledge for organizations. At an optimal rate of turnover, Huselid (1995) assumes that low rates of turnover are preferable to high rates. Employee turnover may be also costly as it requires different cost to take account such as administrative costs of recruitment, cost of covering during the period in which there is a vacancy, training cost for the new worker etc. (Shamsuzzoha and Shumon, 2007). 
Turnover occurs for many different reasons. Sometimes new job attracts employees and pull them to leave the available one. In contrary employee also pushed to leave job due to the dissatisfaction in their present workplace. Poor managerial relationships can be an important reason for the employees to leave their jobs. It is relatively seldom for people to leave jobs in which they are happy even offered by higher salary elsewhere (Shamsuzzoha and Shumon, 2007).

Turnover intention can be either voluntary or involuntary. Voluntary turnover occurs when the employee makes the decision to leave on his own. Usually, voluntary turnover intention occurs when the employee perceives another opportunity as better than his current position. This includes more pay, more recognition or a more convenient location. It can also occur when the employee has to leave for health or family reasons. If an employee plans to voluntarily retire from a position, that's voluntary turnover intention, too. On the other hand, involuntary turnover intention is a measurement of whether the organization in question plans to remove an employee from a position, causing the turnover. This can happen if an organization isn't happy with an employee's job performance and chooses to fire him. It also happens when a business has to eliminate positions due to economic pressures or downturns in business. In general, turnover creates monetary and structural stress on the organization it occurs within, especially voluntary turnover. At least with involuntary turnover, the organization can make preparations to reduce losses. To reduce turnover intention, organizations can offer strategic compensation packages especially with emphasizing performance and tenure. Also, employee-centric businesses tend to have fewer turnovers because the staff feels like it has a voice and the company values its contributions (Price and Mueller 1981).

\section{RESEARCH}

\section{Research goal and hypothesis}

The main objective of this study is to find out the relationships between mobbing, OCB and turnover intention at work. Then it is aimed to investigate whether the demographic characteristics of workers affect the levels of those concepts or not. The model of our research is shown in Figure1. In this context these hypotheses are developed:

H1: There is an inverse relationship between the level of mobbing and OCB.

$\mathrm{H} 2:$ There is an inverse relationship between the level of OCB and turnover intention.

H3: There is a positive relationship between the level of mobbing and turnover intention.

H4: The levels of mobbing, OCB and turnover intention differ according to demographic characteristics of workers.

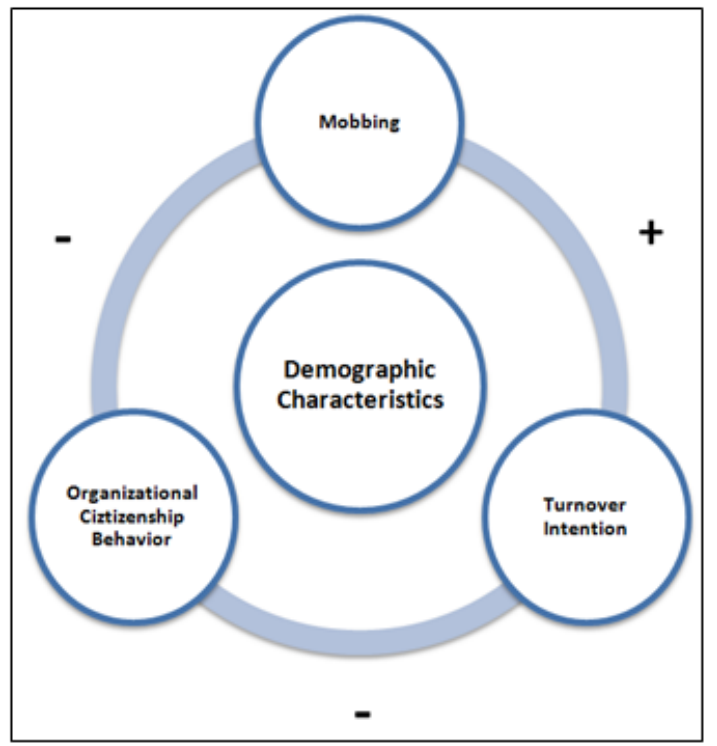

Figure1: Research Model 


\section{Sample and data collection}

To test the hypotheses, a field survey using questionnaires conducted on 171 public and private sector workers in the city of Erzurum located in the Eastern Anatolia/Turkey. Data collected by postgraduate students (Cemil İLBAŞ, Mevlüt YAĞAR, Rovshan ABBASOV, Uğur ŞEN, Yüsuf YİĞİT) attending to Atatürk University Social Sciences Institute Labor Economics and Industrial Relations Program.

The questionnaire consists of two sections. The first section includes questions related to the demographic characteristics of workers and the second section includes 42 items using 5 Likert-Type Scale (1=very low to $5=$ very high). Twenty items are related to mobbing yielded an $\mathrm{r}=0.95$ Cronbach Alpha, 19 items are related to OCB yielded an $\mathrm{r}=0.92$ Cronbach Alpha and 3 items are related to turnover intention yielded an $\mathrm{r}=0.82$ Cronbach Alpha. The Cronbach Alpha values indicate that the scales used in this survey are reliable.

To measure mobbing, 20 items were selected among LIPT Questionnaire (Leymann Inventory of Psychological Terror Questionnaire) (Leymann, 1990a). LIPT includes 5 dimensions and 45 items but we used 20 items which could be convenient and valid to Turkish Culture. The average score of the scale was evaluated as the level of mobbing. Organizational Citizenship Behavior Scale developed by Basım and Şeşen (2006) consists of 19 items including 5 dimensions based on Organ's classification. Finally, to measure turnover intention, the items developed by Cammann et al (1983) were used.

Data obtained from questionnaires was analyzed through the SPSS 16 statistical packet program. Descriptive statistics such as frequency, percentage, mean and standard deviation, for relationships co-relation coefficient and for classification Mann Whitney-U and Kruskal Wallis tests were applied to analyze the collected data. Only observed statistically significant differences were tabulated.

To evaluate means a range table was established shown in Table2. As we used five-point Likert from 1 to 5 , the step range should be found to evaluate means. We found step range as $(5-1) / 5=4 / 5=0.8$. We added this value to 1 and so on. Then the range table included the situations as very low, low, moderate, high and very high.

Table2: Ranges to Evaluate Means
\begin{tabular}{|l|l|}
\hline Range & Evaluation \\
\hline $1.00-1.80$ & Very low \\
\hline $1.81-2.60$ & Low \\
\hline $2.61-3.40$ & Moderate \\
\hline $3.41-4.20$ & High \\
\hline $4.21-5.00$ & Very high \\
\hline
\end{tabular}




\section{Findings}

Table3 shows the demographic characteristics of the workers.

Table3. Demographic Characteristics of the Workers

\begin{tabular}{|c|c|c|}
\hline & Frequency & Percent \\
\hline \multicolumn{3}{|l|}{ Gender } \\
\hline Female & 51 & 29.8 \\
\hline Male & 120 & 70.2 \\
\hline \multicolumn{3}{|l|}{ Marital Status } \\
\hline Married & 88 & 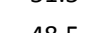 \\
\hline Single & 83 & \\
\hline \multicolumn{3}{|l|}{ Academic Qualification } \\
\hline High School & 87 & 50.9 \\
\hline Vocational High School & 25 & 14.6 \\
\hline Undergraduate & 59 & 24.5 \\
\hline \multicolumn{3}{|l|}{ Age } \\
\hline Up to 25 years & 51 & 29.8 \\
\hline $26-35$ years & 89 & 52.0 \\
\hline More than 35 years & 31 & 18.1 \\
\hline \multicolumn{3}{|l|}{ Managerial Status } \\
\hline Manager & 18 & 10.5 \\
\hline Officer & 153 & 89.5 \\
\hline \multicolumn{3}{|l|}{ Seniority } \\
\hline Up to 1 year & 45 & 26.3 \\
\hline $1-5$ years & 65 & 38.0 \\
\hline $6-10$ years & 27 & 15.8 \\
\hline More than 10 years & 34 & 19.9 \\
\hline \multicolumn{3}{|l|}{ Sector } \\
\hline Private & 74 & 43.3 \\
\hline Public & 97 & 56.7 \\
\hline Total & 171 & 100 \\
\hline
\end{tabular}

Table4 shows the means and evaluations of mobbing, OCB and turnover intention. As seen the level of mobbing and the level of turnover similarly are very low. But the level of OCB is high.

Table4: Means

\begin{tabular}{|c|c|c|}
\hline & MEAN & EVALUATION \\
\hline MOBBING & 1.39 & VERY LOW \\
OCB & 3.82 & HIGH \\
TURNOVER & 1.70 & VERY LOW \\
INTENTION & & \\
\hline
\end{tabular}

We compared the means according to the gender of workers (Table5). When we examine Table6, it can be seen that the level of mobbing and the level of OCB differ in terms of the gender of workers. The mean rank of mobbing for females is higher than males. This finding indicates that female workers are faced more mobbing than males according to their perceptions. On the contrary, the level of OCB for males is higher than females. This finding says males show more OCB than females at work. 
Journal of Global Strategic Management | V. 9 | N. 1 | 2015-June | isma.info | 87-98 | DOI: 10.20460/JGSM.2015915631

Table5. Comparisons According to Gender (Mann Whitney U)

\begin{tabular}{|c|c|c|c|c|c|}
\hline & Gender & Frequency & Mean Rank & Mann Whitney U & $p$ \\
\hline \multirow{2}{*}{ Mobbing } & Female & 51 & 97.44 & \multirow{2}{*}{2476} & \multirow{2}{*}{$0.046 *$} \\
\hline & Male & 120 & 81.14 & & \\
\hline \multirow{2}{*}{ ОСВ } & Female & 51 & 68.33 & \multirow{2}{*}{2159} & \multirow{2}{*}{$0.002 *$} \\
\hline & Male & 120 & 93.51 & & \\
\hline \multirow{2}{*}{ Turnover intention } & Female & 51 & 91.66 & \multirow{2}{*}{2772} & \multirow{2}{*}{0.301} \\
\hline & Male & 120 & 83.60 & & \\
\hline
\end{tabular}

$* \mathbf{P}<\mathbf{0 . 0 5}$

Table6 illustrates the comparison of means according to marital status of workers. According to table, single workers are more likely to intend to turnover.

\section{Table6. Comparisons According to Marital Status (Mann Whitney U)}

\begin{tabular}{|c|c|c|c|c|c|}
\hline & $\begin{array}{c}\text { MARITAL } \\
\text { STATUS }\end{array}$ & FREQUENCY & MEAN RANK & $\begin{array}{c}\text { MANN } \\
\text { WHITNEY U }\end{array}$ & P \\
\hline \multirow{2}{*}{$\begin{array}{c}\text { TURNOVER } \\
\text { INTENTION }\end{array}$} & MARRIED & $\mathbf{8 8}$ & $\mathbf{7 6 . 4 6}$ & & \\
\cline { 2 - 4 } & SINGLE & $\mathbf{8 3}$ & $\mathbf{9 6 . 1 1}$ & \multirow{2}{*}{$\mathbf{2 8 1 2}$} & $\mathbf{0 . 0 0 6 *}$ \\
\hline
\end{tabular}

$* \mathbf{P}<0.05$

Table7 shows the comparison of means according to the sector in which responders work. As seen, private sector workers show more OCB than public sector workers. This might be due to OCB is more necessary in private sector to earn more money, to rise up in the hierarchy etc. In private sector OCB is expected and desired by managers. In spite of this in public sector it is considered adequate if one do what is written in his job description. Interestingly the level of turnover intention is higher in private sector than public. Those workers in private firms may look for better job conditions. Repeatedly, workers in public sector are more stable with their job and generally think to work in available work till retirement.

Table7. Comparisons According to Sector (Mann Whitney U)

\begin{tabular}{|c|c|c|c|c|c|}
\hline & Sector & Frequency & Mean Rank & Mann Whitney U & $p$ \\
\hline \multirow{2}{*}{ ОСВ } & Private & 74 & 96.68 & \multirow{2}{*}{2799} & \multirow{2}{*}{$0.011 *$} \\
\hline & Public & 97 & 77.86 & & \\
\hline \multirow{2}{*}{ Turnover intention } & Private & 74 & 96.97 & \multirow{2}{*}{2777} & \multirow{2}{*}{$0.009 *$} \\
\hline & Public & 97 & 77.63 & & \\
\hline
\end{tabular}

$* \mathrm{p}<0.05$

Table8 illustrates the comparison of means according to the academic qualification of workers. The levels of mobbing and turnover intention differ in terms of academic qualification. To identify different groups LSD test was applied to the data. It can be seen that well educated workers perceive more mobbing than others. This may be because of the awareness about mobbing fact. Beside this the possibility of well educated people being target is higher. Parallel to this finding, they are more likely to intend to turnover. 
Journal of Global Strategic Management | V. 9 | N. 1 | 2015-June | isma.info | 87-98 | DOI: 10.20460/JGSM.2015915631

\section{Table8. Comparisons According to Academic Qualification (Kruskal Wallis)}

\begin{tabular}{|c|c|c|c|c|c|c|}
\hline & Academic Qualification & Frequency & Mean Rank & Difference (LSD test) & Chi-Square & $p$ \\
\hline \multirow{3}{*}{ Mobbing } & High school & 87 & 77.36 & \multirow{3}{*}{$\begin{array}{l}\text { Undergraduate differs from } \\
\text { other }\end{array}$} & \multirow{3}{*}{8.350} & \multirow{3}{*}{$0.015^{*}$} \\
\hline & Vocational high school & 25 & 81.30 & & & \\
\hline & Undergraduate & 59 & 100.74 & & & \\
\hline \multirow{3}{*}{$\begin{array}{l}\text { Turnover } \\
\text { intention }\end{array}$} & High school & 87 & 77.61 & \multirow{3}{*}{$\begin{array}{l}\text { Undergraduate differs from } \\
\text { other }\end{array}$} & \multirow{3}{*}{6.249} & \multirow{3}{*}{0.044} \\
\hline & Vocational high school & 25 & 89.16 & & & \\
\hline & Undergraduate & 59 & 97.03 & & & \\
\hline
\end{tabular}

$* \mathrm{p}<0.05$

When we compared the means according to age, managerial status and seniority of workers, we did not obtain any differences between scores. Based on these results, $\mathrm{H} 4$ (The levels of mobbing, OCB and turnover intention differ according to demographic characteristics of workers) is accepted for gender, marital status, sector and academic qualification of workers.

Table9 demonstrates the relationship between mobbing, OCB and turnover intention. The Pearson Correlation Coefficient between mobbing and OCB is $-0.175 *$, between OCB and turnover intention is 0.132 , and between mobbing and turnover intention is $0.360^{* *}$. SPSS program evaluates $(* *)$ as a strong, and $\left({ }^{*}\right)$ as a moderate relationship between variables while $\left(^{+}\right)$and $(-)$means the direction of the relationship. In the light of this explanation it can be said that there is an inverse and moderate relationship between mobbing and OCB. With this result $\mathrm{H} 1$ (There is an inverse relationship between the level of mobbing and OCB) is accepted. This means the higher the level of mobbing, then the lower the level of OCB. If in an organization OCB is expected and desired, then human resource management especially should control and eliminate mobbing in workplace.

There is no relationship between OCB and turnover intention. When we set up H2, we expected a negative relationship. The Pearson Correlation Coefficient between OCB and turnover intention is -0.132 . In spite of predicting the direction (-) of the relation truly, H2 (There is an inverse relationship between the level of $O C B$ and turnover intention) is not accepted.

Finally, we found a strong and positive relationship between mobbing and turnover intention. With this finding H3 (There is a positive relationship between the level of mobbing and turnover intention) is accepted. This refers to the higher the level of mobbing, then the higher of the level of turnover intention. As mentioned in literature review, people who engage in mobbing has a final goal leads the target (victim) quit the job. From this point of view it can be deduced that high level of mobbing causes high level of turnover intention and turnover rates. This also brings a lot of negative effects of turnover for the organization. Again an organization should be aware of mobbing and take necessary measures to prevent and stop it.

Table9. The Relationship between Mobbing, OCB and Turnover Intention (Pearson Correlation Coefficient)

\begin{tabular}{|l|l|l|l|l|}
\hline & & Mobbing & OCB & Turnover intention \\
\hline \multirow{3}{*}{ Mobbing } & Pearson Correlation & 1 & $-0.175^{*}$ & $0.360^{* *}$ \\
\cline { 2 - 5 } & Sig. (2-tailed) & & 0.022 & 0.000 \\
\hline \multirow{3}{*}{ OCB } & Pearson Correlation & & 1 & -0.132 \\
\cline { 2 - 5 } & Sig. (2-tailed) & & & 0.085 \\
\hline \multirow{2}{*}{ Turnover intention } & Pearson Correlation & & & 1 \\
\cline { 2 - 5 } & Sig. (2-tailed) & & & \\
\hline \multirow{2}{*}{$* *$ Correlation is significant at the 0.01 level (2-tailed). *. Correlation is significant at the 0.05 level (2-tailed). } \\
\hline
\end{tabular}




\section{CONCLUSION}

In this study, we basically try to find out the relationships between mobbing, OCB and turnover intention. Then it is aimed to investigate whether the demographic characteristics of workers affect the levels of these concepts.

As a result of the study, we found out that there was an inverse relationship between mobbing and OCB, whereas there was a strong and positive relationship between mobbing and turnover intention. Rather, there was no relationship between OCB and turnover intention. With these findings we can firstly say that if there is a higher level of mobbing, then the lower level of OCB. If in an organization OCB is expected and desired, then human resource management especially should control and eliminate mobbing in workplace. It is possible to reveal secondly that the higher the level of mobbing is then the higher the level of turnover intention will be. It is argued in literature that people who engage in mobbing have a final goal aimed the target (victim) to quit the job. So, high level of mobbing causes high level of turnover intention and turnover rates. This also means a lot of negative effects of turnover for the organization. Finally, an organization should be aware of mobbing and take necessary measures to prevent and stop it.

We observed that there were statistically significant differences between the levels of mobbing, OCB and turnover intention according to the demographic characteristics of workers. The mean rank of mobbing for females is higher than males. This finding indicates that female workers are faced more mobbing than males according to their perceptions. On the contrary, the level of OCB for males is higher than females. This finding says males show more OCB than females at work. Another result says single workers are more likely to intend to turnover. When we compare means in terms of sector, private sector workers show more OCB than public sector workers. Interestingly the level of turnover intention is higher in private sector than public. Lastly, the levels of mobbing and turnover intention differ in terms of academic qualification. It was found that well educated workers perceive more mobbing than others and they are more likely to intend to turnover.

We found the level of mobbing as very low, the level of OCB as high and the level of turnover intention as very low.

As we conducted the survey to workers in the province of Erzurum, the data is limited to this sample. Further researches can be applied in different organizations, provinces and also countries to generalize the findings. 


\section{REFERENCES}

Abbasi, S. M., Hollman, K. W. and Hayes, R. D. (2008). Bad bosses and how not to be one. Information Management Journal, 42: 52-56.

Adams, A. (1992a). Bullying at work. How to confront and overcome it. London: Virago Press.

Ahmad, B., Shahid, M., Huma, Z.E. and Haider, S. (2012). Turnover intention: An HRM issue in textile sector, Interdisciplinary Journal Of Contemporary Research in Business, 3: 125-130.

Barnard, C. I. (1938). The Functions of the Executive. Cambridge, MA: Harvard University Press.

Basım, H. N. and Şeşen, H. (2006). Örgütsel vatandaşlık ölçeği uyarlama ve karşılaştırma çalışması. Ankara Üniversitesi SBF Dergisi, 61 (4): 83-101.

Brodsky, C.M. (1976). The harassed worker. Lexington, Mass.: D.C. Heath and Company.

Cammann, C., Fichman, M., Jenkins, D., and Klesh, J. (1983), Assessing Organizational Change: A Guide to Methods, Measures, and Practices, Assessing the attitudes and perception of organizational members, Derl.: Seashore, S., E. Lawler, P. Mirvis, C. Cammann (New York: John Wiley \& Sons).

Coleman, V. I. and W.C. Borman, W. C. (2000). Investigating the underlying structure of the citizenship performance domain. Human Resource Managemen Review, 10 (2000): 25-44.

Cotton, J. and Tuttle, J. (1986). Employee turnover: A meta-analysis and review with implications for research. Academic Management Review, 11: 55-70.

Dalton, D., W. Todor. 1979. Turnover turned over: An expanded and positive perspective. Acad. Management Rev. 4(2) 225-235.

Denenberg, R. \& Braverman, M. (2001). The violence prone workplace: A new approach to dealing with hostile, threatening, and uncivil behavior. Ithaca: Cornell University Press.

Einarsen, S., \& Raknes, B. (1997). Harassment in the Workplace and the Victimization of Men. Violence and Victims, 12(3), 247-263.

Garino, G. and Martin, C. (2007). The Impact of Labor Turnover: Theory And Evidence From Uk MicroData, Working Paper, University of Leicester, Department of Economics.

Heinemann, P.P (1972). Mobbning-Gruppvåld bland barn och vuxna. Stockholm: Natur \& Kultur.

Huselid, M. 1995. The impact of human resource management practices on turnover, productivity, and corporate financial performance. Acad. Management J. 38(3) 635-672.

Katz, D. and Kahn, R. L. (1978). he Social Psychology of Organizations, New York.

Keashly, L. (1998). Emotional abuse in the workplace. Journal of Emotional Abuse, 1, 85-117.

Kolade, O. J., Oluyese, O. O. and Omotayo, O. (2014).Organizational Citizenship Behavior, Hospital Corporate Image and Performance, Journal of Competitiveness, 6 (1): 36-49.

Leymann, H. (1990a). Manual of the LIPT questionnaire for assessing the risk of psychological violence at work. Stockholm: Violen.

Leymann, H. (1990b). Mobbing and psychological terror at workplaces. Violence and Victims, 5 (2), 119126.

Leymann, H. (1993). Atiologie und Haufigkeit von Mobbing am Arbeitplatz : Eine Ubersicht über die Bisherige Forschung. Zeitschrift fuer Personalforschung,7, 271- 284

Leymann, H. (1996). The content and development of mobbing at work. European Journal of Work and Organizational Psychology, 5 (2): 165-184. 
Leymann, H. and Gustavsson, B. (1984). Psykiskt void i arbetslivet. Tvd explorativa undersokningar [Psychological violence at work places. Two explorative studies]. (Undersokningsrapport 42.), Arbetarskyddsstyrelsen: Stockholm.

Lorenz, K. (1991). Hier bin ich-wo bist Do? Ethologie der graugans, München, Piper.

Organ, D. W. (1988). Organizational Citizenship Behavior: The Good Soldier Syndrome. Lexington, MA: Lexington Books.

Price, J.L. and Mueller, C.W. (1981). A causal model of turnover for nurses. Academy of Management Journal, 24: 543-65.

Shallcross, L., Sheehan, M. and Ramsay, S. (2008). Workplace mobbing: experiences in the public sector. International Journal of Organizational Behavior, Volume 13(2): 56-70.

Shamsuzzoha, A. H. M., \& Shumon, M. R. H. (2007). Employee TurnoverA Study of its Causes and Effects to Different Industries in Bangladesh. Manufacturing Engineering, 6 (3): 64-68.

Sloan, L.M., Matyók, T., , Schmitz, C. L. , and Short, G.F.L. (2010). A Story to Tell: Bullying and Mobbing in the Workplace. International Journal of Business and Social Science, 1(3): 87-97.

Tett, R. P. and Meyer, J. P. (1993). Job satisfaction, organizational commitment, turnover intention and turnover: Path analysis based on meta-analytical findings. Personal Psychology, 46(2): 259-293.

VanDyne, L. and LePine, J. A. (1998). Helping and voice extra-role behaviors: Evidence of construct and predictive validity, Acad Manage J, 1 (41): 108-119.

Westhues, K. (2003). The mobbings at Medaille College in 2002. New York Academe, 30 (1), 8-10.

Zhang, D. (2011). Organizational Citizenship Behavior, PSYCH761 White Paper. 